\title{
PEMANFAATAN LINGKUNGAN SEKOLAH SEBAGAI SUMBER BELAJAR IPS
}

\author{
${ }^{1)}$ Nurlaili Dina Hafni, Prodi PGMI, Fakultas Tarbiyah, IAINU Tuban \\ email : dinahafni@stitmatuban.ac.id
}

\begin{abstract}
Social studies is a subject that uses an integrated approach that combines four fields of study, namely economics, sociology, geography and history. Integrated learning is intended to provide meaningful experiences to students and in their delivery the teacher chooses a specific theme or topic, this learning approach enables students both individually and in groups to actively seek, explore and discover concepts and principles holistically and authentically. The way the teacher packaging the learning is very influential on the meaningful experience for the students. The surrounding environment as a learning resource is very beneficial for the social studies learning process, this is because the learning resources are close to students, so students are easier in the process of understanding the learning resources. The environment can provide a picture that is holistic and authentic, the condition is very heterogeneous, so it shows a source of learning that requires integration between learning materials. This environmental potential can be in the form of social, economic, cultural and geographic environments. Linking class to the community environment provides many opportunities for students to learn the basic ability to take action in the community in the form of participation.
\end{abstract}

Keywords: environment, learning resources,social studies

\section{Pendahuluan}

Ilmu Pengetahuan Sosial (IPS) adalah pembelajaran yang mempelajari tentang fenomenafenomena yang terjadi di masyarakat baik masa lalu, masa sekarang, dan kecenderungannya di masa-masa mendatang. Pembelajaran IPS di sekolah masih banyak mengalami kendala. Yaitu belum memaksimalkan pemanfaatan lingkungan alam sebagai sumber dan media pembelajaran. Guru dalam perencanaan pembelajaran belum mengembangkan materi pembelajaran yang terkait dengan lingkungan alam sekitar. Peserta didik menjadi kurang aktif dan bahkan tidak fokus dalam mengikuti pembelajaran yang ada karena media pembelajara yang monoton. Sangat diperlukan terobosan kreativitas dan inovasi pembelajaran mesti diselaraskan dengan tingkat perkembangan anak dan tuntutan zaman dengan tetap mengacu pada akurasi data yang dapat dipertanggugjawabkan. Termasuk pembelajaran di luar ruang dalam hal ini lingkungan sekitar. Yang dimaksud lingkungan disini adalah semua benda dan kondisi termasuk di dalamnya manusia dan aktifitasnya, yang terdapat dalam ruang dimana manusia berada dan mempengaruhi 
kelangsungan hidup serta kesejahteraan hidup dan jasad renik lainnya. harus semakin dioptimalkan ${ }^{1}$.

Salah satu kelemahan dalam pembelajaran IPS adalah menekankan pada strategi ceramah dan ekspositori atau transfer of knowledge yang menjadikan guru sebagai pusat kegiatan belajar mengajar". Sehingga secara substansial seakan-akan proses pembelajaran lebih didominasi guru tanpa memberikan akses keterlibatan siswa secara aktif, kreatif dan inovatif dalam proses pemebelajaran ${ }^{2}$. Padahal secara hakiki, perkembangan intelektual siswa pada usia Sekolah Dasar berada pada fase operasional konkret (concrete operations).

Salah satu permasalahan yang sangat mendasar dalam pembelajaran IPS di Sekolah Dasar adalah rendahnya daya serap siswa terhadap pemahaman materi pembelajaran yang disajikan guru. Tentunya banyak hal yang mempengaruhinya, seperti karakteristik materi, tingkat ketersediaan dan keterbacaan buku teks, metode dan model pendekatan pembelajaran yang diterapkan guru. Namun kenyataan di lapangan, dari berbagai penyebab tersebut ternyata yang paling urgen dan esensial keberadaannya adalah masih banyaknya guru yang menerapkan model pembelajaran konvensional dalam membelajarkan materi IPS di Sekolah Dasar yang ternyata belum mampu menyentuh esensi dasar kebutuhan belajar dan kebutuhan perkembangan siswa. Sementara itu lingkup materi IPS mengkaji tentang manusia dan lingkungannya dengan segala fenomena yang terdapat di dalamnya.

Ilmu Pengetahuan Sosial adalah bidang-bidang yang digali dari kehidupan praktis sehari-hari di masyarakat ${ }^{3}$. Oleh karena itu, pengajaran IPS yang melupakan masyarakat sebagai sumber dan obyeknya, merupakan suatu bidang pengetahuan yang tidak berpijak kepada kenyataan. IPS yang tidak bersumber kepada kenyataan tidak mungkin mencapai sasaran dan tujuannya, dan tidak akan memenuhi tuntutan kemasyarakatan.

Dengan menggunakan lingkungan sebagai sumber belajar, diharapkan siswa akan memiliki kepedulian terhadap lingkungannya, dan berawal dari pemahaman konsep dan kepedulian itu, siswa dapat mencari solusi, mengambil keputusan, dan melakukan tindakan nyata ketika menghadapi masalah dalam lingkungan mereka sendiri. Bertolak dari pandangan tersebut, maka dinilai perlu untuk sesegera mungkin memperbaharui paradigma pembelajaran IPS yang

${ }^{1}$ St. Munadjat Danusaputro, Hukum Lingkungan Buku I: Umum (Bandung: Binacipta, 1980) hal. 46

${ }^{2}$ Somantri, M.Numan, Menggagas Pembaharuan Pendidikan IPS. (Bandung: Remaja Rosdakarya Offset, 2001) hal 54

${ }^{3}$ Nursid Sumaatmaja, Manusia Dalam Konteks Sosial Budaya Dan Lingkungan Hidup (Bandung: Alfabeta, 1998) hal 16. 
mampu menyentuh kebutuhan esesnsi belajar siswa, sehingga belajar IPS menjadi lebih bermakna bagi kehidupan siswa dalam lingkungan masyarakatnya. Untuk memfasilitasi hal tersebut, maka guru hendaknya senantiasa berupaya untuk mendekatkan materi kajian IPS dengan lingkungan keseharian hidup siswa. Karena lingkungan, baik lingkungan fisik, sosial, maupun lingkungan budaya merupakan media dan sumber belajar yang kaya dengan berbagai konsep, dan nilai serta moral dan norma yang dapat mengembangkan sikap kepedulian sosial siswa dan mengimplementasikannya dalam kehidupan bermasyarakat.

Penerapan model pendekatan pemanfaatan lingkungan sebagai sumber belajar IPS, diharapkan menjadi salah satu alternatif pilihan guru dalam membelajarkan materi kajian IPS di Sekolah Dasar. Karena pemanfaatan lingkungan sebagai media dan sumber belajar, sangat relevan dengan karakteristik fase perkembangan siswa kelas tiga Sekolah Dasar yang masih terbatas pada tataran kemampuan operasional konkret. Dengan demikian diharapkan melalui penerapan model pendekatan kontekstual dengan memanfaatkan lingkungan sebagai media dan sumber belajar IPS, motivasi, aktivitas, kreativitas, dan gairah belajar siswa menjadi meningkat, dan ada akhirnya timbul sikap baru menyenagi pembelajaran IPS.

\section{Kajian Pustaka}

\section{Ilmu Pengetahuan Sosial}

Ilmu Pengetahuan Sosial dirumuskan atas dasar realitas dan fenomena sosial yang mewujudkan suatu pendekatan interdisipliner dari aspek dan cabang-cabang ilmu-ilmu sosial yaitu sosiologi, sejarah, gerografi, ekonomi, politik, hukum dan budaya. geografi, sejarah dan antropologi merupakan disiplin ilmu yang mempunyai keterpaduan yang tinggi, dimana aspekaspek kehidupan masyarakat merupakan bidang kajian dari IPS, sehingga dalam penyampaiannya sebaiknya secara terpadu atau terintegrasi, agar siswa mendapatkan pemahaman yang bulat dari lingkungannya. IPS mempunyai konsep: interaksi, saling ketergantungan, kesinambungan dan perubahan, keragaman/kesamaan/ perbedaan, konflik dan konsesus, pola (patron), nilai kepercayaan, keadilan pemerataan dan lain-lain ${ }^{4}$.

\section{Sumber Belajar}

Sumber belajar merupakan suatu komponen yang sangat penting dalam proses pembelajaran, sebab sumber belajar akan memudahkan siswa dalam memahami materi yang

\footnotetext{
${ }^{4}$ Trianto, Model Pembelajaran Terpadu (Jakarta: Bumi Aksara, 2011) hal 89
} 
diberikan oleh guru. Penyampaian sumber belajar kepada siswa akan melalui suatu media yaitu media belajar, lewat media ini makna dari suatu sumber akan dapat diterima dan dipahami oleh siswa.

\section{Metodologi}

Penelitian ini menggunakan pendekatan kualitatif dengan desain studi kasus. Penelitian dilaksanakan di SDN Tasikmadu 02 Palang Tuban. Penelitian dilakukan dengan menggali informasi mengenai tentang peran lembaga pendidikan dalam peningkatan kualitas pendidik anak usia dini melalui pendidikan dan pelatihan di SDN Tasikmadu 02 Palang. Pengumpulan data menggunakan observasi dan wawancara. Untuk menjamin keabsahan data, digunakan pengujian konfirmabilitas atau uji objektivitas penelitian. Uji konfirmabilitas dilakukan setelah melaksanakan observasi, yakni dengan melakukan wawancara. Dari hasil pengamatan yang telah dilakukan, kemudian dilakukan konfirmasi kepada kepala lembaga dan kepada guru untuk menguji apakah informasi yang didapatkan benar adanya menurut narasumber.

\section{Hasil}

\section{Kreativitas Guru Dalam Merencanakan Pemanfaatan Lingkungan Sekolah Sebagai Sumber Belajar Siswa}

Sebagai upaya untuk meningkatkan kualitas pembelajaran mata pelajaran IPS di SDN Tasikmadu 02 Palang Tuban seorang guru dituntut kreatif dalam proses pembelajaran. Salah satu upayanya yaitu kreatif dalam merencanakan proses pembelajaran. Hal tersebut sesuai dengan pendapat E. Mulyasa dalam bukunya "Menjadi Guru Profesional" bahwa guru yang kreatif yaitu guru yang mempunyai kemampuan dalam mengoptimalkan kemampuan daya pikirnya untuk mengemas kegiatan pembelajaran menjadi pembelajaran yang mudah diterima peserta didik, mengatasi masalah-masalah pembelajaran, memberikan trobosan-trobosan solusi untuk mengatasi masalah, dengan berbagai cara serta memberikan semangat siswa dalam belajar sehingga dampak kreatif seorang guru tersebut adalah situasi belajar mengajar yang efektif dan mencapai tujuan pembelajaran yang diinginkan ${ }^{5}$. Hal tersebut juga didukung pendapat Syaifurahman dan Tri Ujati dalam bukunya "Manajemen dalam Pembelajaran" bahwa sebagai seorang pendidik, guru tidak boleh cepat berpuas diri dan menganggap bahwa cara mengajar

\footnotetext{
${ }^{5}$ Mulyasa, Menjadi Guru Profesional, ( Bandung: PT Remaja Rosdakarya, 2005), hal. 52
} 
bahwa cara mengajar dan mendidik sudah hampir sempurna. Guru harus kreatif dalam revisirevisi pembelajaran mulai dari persiapan, rencana pembelajaran, evaluasi dan remedialnya. Selain itu guru harus terbuka terhadap gagasan dan hal-hal baru dalam dunia pendidikan ${ }^{6}$.

Guru-guru di dalam mengajar pembelajaran tematik membuat perencanaan pembelajaran sebelum mengajar. Dimana guru harus membuat perencanaan tentang strategi, metode, dan sumber belajar yang akan digunakan. Dalam menentukan dan memilih sumber belajar, guru harus mempertimbangkan sumber belajar yang sesuai dengan materi yang diajarkan. Hal ini bertujuan agar proses pembelajaran berhasil dan dapat mencapai tujuan pembelajaran. Hal tersebut sesuai dengan pendapat Wina Sanjaya dalam bukunya "Perencanaan dan Desain Sistem Pembelajaran" bahwa sumber belajar yang dipilih dapat dipakai untuk mencapai tujuan/kompetensi yang ingin dicapai, sumber belajar yang dipilih dapat memudahkan pemahaman peserta didik, dan sumber belajar yang dipilih sesuai dengan tingkat perkembangan kogniti, karakteristik afektif, dan keterampilan motorik peserta $\operatorname{didik}^{7}$.

Dalam merencanakan proses pembelajaran terutama pada mata pelajaran IPS selain menentukan strategi, metode dan sumber belajar yang digunakan, guru juga harus mengidentifikasi setiap tema yang akan diajarkan dan mengaitkan materi dengan lingkungan. Seperti yang diketahui bahwa pembelajaran tematik itu bersifat saintifik dan merupakan perpaduan dari beberapa mata pelajaran. Di dalam kurikulum K13 merupakan sebuah kurikulum yang lebih menekankan untuk mencari bakat dan minat dari siswa. Hal tersebut sesuai dengan pendapat Rusman dalam bukunya "Pembelajaran Tematik Terpadu, Teori, Praktik dan Penilaian" bahwa Tahapan dalam pembelajaran tematik melalui beberapa tahap yaitu: pertama, guru harus mengacu pada tema sebagai pemersatu berbagai muatan mata pelajaran untuk satu tahun. Kedua guru melakukan analisis Standar Kompetensi Lulusan, Kompetensi Inti, Kompetensi Dasar dan membuat indikator dengan tetap memerhatikan muatan materi dari Standar Isi. Ketiga membuat hubungan pemetaan antara kompetensi dasar dan indikator dengan tema. Keempat membuat jaringan $\mathrm{KD}$, indikator. Kelima menyusun silabus tematik dan keenam membuat rencana pelaksanaan pembelajaran tematik dengan menerapkan pendekatan saintifik ${ }^{8}$.

\footnotetext{
${ }^{6}$ Syaifurahman dan Tri UJiati, Manajemen Dalam Pembelajaran, (Jakarta: Indeks, 2013), hal.33-35.

${ }^{7}$ Wina Sanjaya, Perencanaan dan Desain ...., hal. 228-230.

${ }^{8}$ Rusman, Pembelajaran Tematik Terpadu Teori, Praktik dan Penilaian (Jakarta: Raja Grafindo Persada, 2015), hal. 150
} 
Dalam perencanaan pemanfaatan sumber belajar, guru-guru menyesuaikan dengan tujuan pembelajaran yang ingin dicapai dan memperhatikan karakteristik siswa. Selain itu, guru-guru juga menyesuaikan dengan perkembangan teknologi yang ada, yang dapat dijadikan sebagai sumber belajar siswa dan mampu menciptakan ide-ide baru dalam memanfaatkan sumber belajar yang tersedia di lingkungan sekolah.

Hal tersebut sesuai dengan pendapat Mulyana dalam bukunya "Rahasia Menjadi Guru Hebat" bahwa untuk mengembangkan potensi siswa, dibutuhkan guru yang kreatif, dan guru yang kreatif mempunyai ciri-ciri sebagai berikut: ${ }^{9}$

1. Fluency, yaitu guru mampu menghasilkan ide-ide yang akurat sesuai dengan masalah yang dihadapi.

2. Fleksibility yaitu guru mampu membuka pikiran

3. Originality yaitu guru mampu menciptakan ide baru.

4. Mudah bergaul, guru yang mudah bergaul bisa dengan mudah menjalin hubungan dengan siswa

5. Mampu membaca karakter siswa

6. Peduli dengan siswa

7. Cekatan

Setelah menghubungan temuan data yang ada di lapangan dengan teori, peneliti menemukan bahwa dalam guru-guru yang ada di MI Nurul Islam Mirigambar cukup kreatif dalam merencanakan proses pembelajaran dan menentukan sumber belajar yang tepat. Sebelum melaksanakan proses pembelajaran guru-guru membuat perencanaan pelaksanaan pembelajaran (RPP), di dalam RPP tersebut guru di haruskan untuk menentukan tujuan pembelajaran dan menentukan sumber belajar yang akan digunakan yang sesuai dengan materi yang akan disampaikan. Di dalam RPP guru juga menyusun kegiatan pembelajaran, yang juga di sesuaikan dengan karakter siswa.

\section{Strategi Pembelajaran Ilmu Pengetahuan Sosial (IPS)}

Secara koseptual pembelajaran terpadu merupakan suatu pengembangan pembelajaran yang dapat berupa aplikasi, pemahaman, analisis dan evaluasi dari mata pelajaran IPS. Program pembelajaran disusun dari bebagai bidang ilmu yang serumpun yaitu sejarah, geografi, ekonomi dan sosiologi, caranya dengan mengambil suatu topik atau tema dari cabang ilmu tertentu,

\footnotetext{
${ }^{9}$ Mulyana A. Z., Rahasia menjadi Guru Hebat, (Surabaya: Grasindo, 2010), hal. 138-140
} 
kemudian dilengkapi, dibahas, diperluas dan diperdalam dengan cabangcabang ilmu lain. Topik atau tema yang dikembangkan dapat berupa isu, peristiwa, dan permasalahan yang berkembang, contoh adalah banjir, TKI, IPTEK, mobilitas sosial dan sebagainya.

Model pembelajaran yang dikembangkan dapat berdasarkan potensi utama suatu wilayah, permasalahan maupun topik tertentu, tetapi tetap harus memperhatikan keterkaitan antar Kompetensi Dasar pada satu rumpun bidang yang telah dipetakan. Topik-topik atau tema yang ditentukan seringkali hanya berdasarkan buku pegangan guru, kreatifitas guru dalam langkah ini harus terus ditingkatkan. Dalam penyampaian materi guru terjebak dengan buku yang dijadikan pedoman.

Pelaksanaan pembelajaran dengan konsep pembelajaran terpadu tentunya mempunyai manfaat antara lain: penghematan waktu, karena bidang-idang ilmu yang serumpun tersebut dapat dibelajarkan secara bersamaan, tumpang tindih materi juga dapat diminimalkan, peserta didik dapat melihat hubungan yang bermakna antar konsep bidang ilmu, meningkatkan taraf kecakapan berpikir peserta didik, karena dihadapkan pada gagasan atau pemikiran yang lebih luas dan mendalam, menyajikan penerapan atau aplikasi tentang dunia nyata yang dialami dilihat dalam kehidupan sehari-hari ${ }^{10}$.

\section{Metode Pembelajaran Ilmu Pengetahuan Sosial}

Proses belajar mengajar bukanlah sekedar menyampaikan informasi ataupun gagasan seperti yang saat ini sering dilakukan oleh guru bidang studi IPS. Didalamnya tercakup pula kegiatan lain yaitu membimbing siswa untuk belajar melalui kegiatan-kegiatan pemeriksaan (probing), menemukan (discovering), menganalisis (analyzing) dan menguji (examining), sebagai sesuatu yang penting dalam membangun sikap dan nilai-nilai serta tugas mengembangkan kerampilan, sehingga dapat dikatakan bahwa tugas seorang guru terutama guru bidang studi IPS adalah menyelaraskan kemampuan soft skill dan hard skill siswa (Permendikbud No 54 Tahun 2013).

Mata Pelajaran atau bidang studi IPS seringkali dianggap sebagai pelajaran ketrampilan, karena menyangkut berbagai hal yang dibutuhkan oleh seseorang sebagai warga masyarakat ataupun sebagai warga negara. Agar proses pembelajaran IPS dapat berlangsung dengan baik dan sesuai dengan tujuan pembelajaran, maka seorang guru IPS harus menentukan metode pembelajaran dengan tepat. Metode tersebut harus merupakan sesuatu yang sudah disusun dan

\footnotetext{
${ }^{10}$ Trianto, Model Pembelajaran Terpadu (Jakarta: Bumi Aksara, 2011) hal 103
} 
dikembangkan guru bukan sekedar kegiatan rutin. Kegiatan atau sumbangan guru harus merupakan sesuatu yang didasarkan pada kekinian, yang hanya mungkin melalui pengalaman. Metode yang baik adalah mampu menghubungkan dirinya dengan pengalaman siswa ${ }^{11}$.

Ketrampilan dan metode yang digunakan guru bidang studi IPS secara langsung akan berdampak atau berpengaruh pada pelajaran IPS, ketrampilan tersebut antara lain : pertama, mengajar bagaimana memahami terutama tentang konsep dan generalisasi; kedua, mengajar sikap, minat dan nilai-nilai, maksudnya adalah mengajarkan sikap dan penghargaan adalah sesuatu yang ideal, minat, nilai-nilai dan karakter moral dan etika adalah lebih sulit tetapi sangat penting karena merupakan kebutuhan bangsa dan negara; ketiga, mengajar bagaimana berpikir hal ini menunjuk pada suatu proses, yaitu suatu proses mental dimana seseorang berinteraksi dengan data dan informasi untuk memperoleh pengetahuan.

Model dan metode mengajar merupakan pengetahuan dasar yang harus dipahami oleh seorang guru bidang studi IPS. Dalam mengajar bidang studi IPS pemahaman guru tentang karakteristik siswa dan metode mengajar merupakan salah satu bagian penting bagi profesi guru. Mengajar bidang studi IPS bertujuan membantu dan mendorong siswa untuk berkipir, karena dalam kegiatan berpikir para siswa harus berhadapan dengan permasalahan yang dekat dengan lingkungannya dan kebutuhan baik untuk sekarang maupun yang akan datang.

Pada kenyataannya terdapat berbagai metode dan teknik serta strategi dalam pengajaran IPS, maka seharusnya guru bidang studi IPS mampu menggunakan metode mengajar secara tepat sesuai dengan tema atau materi yang disampaikan. Berbagai metode mengajar utama dan yang sering dilakukan oleh seorang guru bidang studi IPS antara lain: metode ceramah, hal ini dilakukan karena bidang studi IPS berisi data, informasi, serta konsep dan generalisasi, maka hampir dipastikan menggunakan metode caramah.

Penggunaan metode ceramah dengan berbagai variasi diharapkan dapat meningkatkan kemampuan siswa untuk berdialog, berpikir, berpartisipasi, memilih untuk tidak setuju, atau memilih sikap toleransi terhadap ketidaksetujuan orang lain. Variasi metode ceramah yang berorientasi pada Cara Belajar Siswa Aktif (CBSA) memungkinkan guru untuk melakukan berbagai hal antara lain: Tanya jawab, diskusi kelompok, melakukan tugas, melakukan simulasi dan menyususn laporan. Kombinasi berbagai metode mengajar dalam satu pertemuan sangat

\footnotetext{
${ }^{11}$ Abdul Azis Wahab, Metode dan Model-Model Mengajar Ilmu Pengetahuan Sosial (IPS).( Bandung : Alfabeta, 2007) hal 142
} 
dimungkinkan dilakukan oleh seorang guru bidang studi IPS. Penggunaan berbagai metode yang bervariasi dalam pembelajaran bidang studi IPS yang dimaksudkan untuk mengaktifkan siswa dalam belajar akan sangat bermanfaat bagi pengembangan materi IPS.

\section{Pemanfaatan Lingkungan sebagai Sumber Belajar}

Sumber belajar yang digunakan dalam proses pembelajaran IPS akan lebih mudah dipahami oleh peserta didik apabila guru memanfaatkan lingkungan sekitar. Potensi lingkungan sangat variatif, sehingga merupakan sumber belajar yang potensial dan mudah ditemui serta dipahami peserta didik. Potensi lingkungan ini bisa berupa lingkungan sosial, ekonomi, budaya dan geografi.

Lingkungan sosial dapat berupa pola-pola interaksi yang dilakkan oleh masyarakat, kesadaran akan manfaat pendidikan, mobilitas social, kesehatan dan hidup bersih. Lingkungan ekonomi berupa mata pencharian masyarakat setempat, potensi wisata, kegiatan ekonomi masyarakat sekitar, bentuk-bentuk usaha masyarakat. Lingkungan budaya dapat berupa adat istiadat masyarakat, gaya hidup masyarakat dan keberagaman agama atau kepercayaan. Lingkungan geografi misalnya berupa relief bumi, cuaca, letak geografis dll.

Proses pembelajaran yang dilakukan oleh seorang guru akan mudah diterima oleh siswa apabila digunakan media belajar dan sumber belajar yang jelas. Termasuk guru bidang studi IPS, sebab dalam pembelajaran IPS menyangkut empat dimensi yaitu dimensi pengetahuan (knowledge), dimensi ketrmpilan (skills), dimensi nilai dan sikap (value and attitudes), serta dimensi tindakan (action). Agar dimensi-dimensi tersebut tercapai, maka guru bidang studi IPS selain memilih metode yang tepat juga harus memilih sumber-sumber belajar dan media belajar yang mudah dipahami siswa.

Di era globalisasi yang ditandai dengan perubahan IPTEK yang cepat, dimensi-dimensi tersebut diperlukan untuk menghadapi kehidupan secara efektif dalam kondisi sumber daya alam semakin menipis dan ditandai dengan keragaman etnis, pluralism budaya dan semakin saling ketegantungan. Untuk menyiapkan siswa agar dapat menghadapi berbagai tantangan, maka dalam pembelajaran bidang studi IPS perlu dikembangkan kepekaan sosial dan partisipasi sosial.

Kepekaan sosial atau social sensitivity diperlukan agar siswa mudah bereaksi tehadap masalah-masalah sosial dan masyarakat. Alam kehidupan masyarakat terdapat banyak masalah dan akan menjadi bagian perhatian siswa, sehingga perlu dikembangkan sejak awal. Pengembangan strategi pembelajaran yang dilakukan guru bidang stui IPS hendaknya dapat 
mendorong siswa untuk peka terhadap masalah-masalah yang ada di lingkungan sekitarnya. Kepekaan sosial dapat dikembangkan melalui proses pembelajaran dan pelatihan, sehingga siswa mempunyai pengalaman individual pada masa lampau.

Dengan belajar IPS hendaknya dapat memberdayakan siswa, sehingga segala potensi dan kemampuanya baik pengetahuan, sikap, maupun ketrampilan dapat berkembang. Menurut Jaromelik dan Parker mengemukakan bahwa ujian yang sesungguhnya dalam belajar IPS terjadi ketika siswa berada di luar sekolah. Berdasarkan pendapat tersebut guru bidang studi IPS dalam pembelajarannya hendaknya bertujuan menyiapkan siswa untuk mampu menemukan, memahami dan dapat menghadapi berbagai permasalahan yang ada di lingkungannya ${ }^{12}$. Agar siswa dapat memahami lingkungannya dengan baik, maka guru bidang studi IPS sudah selayaknya menggunakan potensi yang ada di sekitarnya baik potensi geografi, sosial, ekonomi dan budaya sebagai sumber belajar maupun media belajar.

Media-media sekitar sebetulnya potesial untuk membantu siswa dalam melaksanakan mendekatan inkuiri dan melatih ketrampilan berpikir kritis. Kegiatan-kegiatan kesenian yang berupa nyanyian, musik maupun seni lukis yang dalam kegiatannya tidak perlu keluar sekolah, berdasarkan informasi yang didapat sama sekali tidak digunakan dalam pembelajaran IPS.

Mengkaitkan kelas dengan lingkungan masyarakat memberikan banyak kesempatan kepada siswa untuk mempelajari kemampuan dasar untuk melakukan tindakan (action) di masyarakat dalam bentuk partisipasi. Di dalam masyarakat terdapat sejumlah kegiatan yang memungkinkan siswa dapat melakukan actionnya antara lain: kegiatan sosial politik, proyek kemasyarakatan, proyek sosial (sukarelawan), studi kemasyarakatan, permagangan dan program model. Untuk dapat memberikan berbagai ketrampilan yang dibutuhkan siswa, sebaiknya guru bidang studi IPS betul-betul memanfaatkan potensi lingkungannya sebagai sumber belajar dan media belajar. Oleh karenanya dapat dikatakan bahwa guru bidang studi IPS masih banyak yang tidak memanfaatkan potensi sekitarnya dalam pembelajaran, sehingga sumber belajar yang berdasarkan potensi sekitar belum dikembangkan secara maksimal.

Pemanfaatan lingkungan sebagai sumber belajar dapat dilakukan oleh guru dengan memanfaatkan lingkungan sekitar sekolah. Siswa diajak untuk mengamati lingkungan sekitar sekolah yang berkaitan dengan materi pembelajaran geografi yaitu pelestarian lingkungan hidup dan kaitannya dengan pembangunan berkelanjutan, dari pembelajaran tersebut siswa dapat

\footnotetext{
${ }^{12}$ Sapriya, Pengajaran IPS, Konsep dan Pengajaran (Bandung : Remaja Rosda Karya, 2011) hal 87
} 
secara langsung belajar di lingkungan sekitarnya dan kemudian dihubungkan dengan materi pembelajaran. Dimana siswa dapat mengenal berbagai komponen ekosistem yang ada seperti komponen biotik dan abiotik, yang berkaitan dengan terciptanya pembangunan berkelanjutan. Selain itu siswa dapat melihat keadaan kondisi alam sekitar dan mampu mengaitkannya dengan tindakan-tindakan pelestarian lingkungan hidup.

Pemanfaatan lingkungan sebagai sumber belajar memungkinkan siswa belajar secara langsung fenomena alam berdasarkan pengamatan sendiri. Kegiatan belajar di luar kelas ini menekankan pada kegiatan pembelajaran yang dikaitkan dengan situasi dunia nyata. Selain dapat membuka wawasan berpikir yang beragam dari seluruh siswa, pemanfaatan lingkungan alam sekitar memungkinkan siswa dapat mempelajari berbagai konsep dan cara mengaitkannya dengan dunia nyata, sehingga hasil belajarnya lebih berdaya guna bagi kehidupannya. Dengan memanfaatkan lingkungan sebagai sumber belajar, proses belajar mengajar menjadi menarik dan tidak terkesan membosankan dan membuat siswa lebih memahami materi yang terdapat di buku pelajaran dengan melihat keadaan yang sebenarnya di lapangan, sehingga pembelajaran berlangsung dengan nyata dan dengan memanfaatkan lingkungan sebagai sumber belajar diharapkan dapat membuat proses belajar mengajar lebih efektif dan memberikan pengaruh positif terhadap hasil belajar siswa yang lebih baik.

Lingkungan digunakan sebagai sumber belajar memiliki keuntungan sebagai berikut,

a. kegiatan belajar lebih menarik dan tidak membosankan siswa duduk di kelas berjamjam, sehingga, motivasi belajar siswa akan lebih tinggi

b. hakikat belajar akan lebih bermakna sebab siswa dihadapkan dengan situasi dan keadaan yang sebenarnya atau bersifat alami

c. Bahan-bahan yang dapat dipelajari lebih kaya serta lebih faktual sehingga kebenarannya lebih akurat

d. Kegiatan belajar siswa lebih komprehensif dan lebih aktif sebab dapat dilakukan dengan berbagai cara seperti mengamati, bertanya atau wawancara, membuktikan atau mendemonstrasikan, menguji fakta, dan lain-lain

e. Sumber belajar menjadi lebih kaya sebab lingkungan yang dapat dipelajari bisa beraneka ragam seperti lingkungan sosial, lingkungan alam, lingkungan buatan, dan lain-lain 
f. Siswa dapat memahami dan menghayati aspek-aspek kehidupan yang ada di lingkungannya, sehingga dapat membentuk pribadi yang tidak asing dengan kehidupan di sekitarnya, serta dapat memupuk cinta lingkungan

\section{Proses Pemanfaatan Lingkungan Sekolah Sebagai Sumber Belajar IPS oleh Guru- guru SDN Tasikmadu 02 Palang Tuban}

\section{1) Perencanaan}

Perencanaan yang dimaksudkan dalam hal ini adalah pembuatan RPP juga pengidentifikasi potensi lingkungan sekolah yang dapat digunakan sebagai sumber belajar IPS. Hal pertama yang perlu dilakukan oleh seorang guru adalah mencari potensi lingkungan sekolah yang dapat dijadikan sumber belajar IPS. Berdasarkan pada wawancara dan dokumentasi pada guru IPS maka dapat diketahui bahwa sebagian besar guru telah merencanakan pembelajaran dengan membuat RPP. Rencana pembelajaran yang menggunakan lingkungan sebagai sumber belajar dan sumber materi pelajaran terdapat pada beberapa materi dan pada setiap kelas. Kemudian setelah inventarisasi potensi lingkungan sekolah, guru dapat membuat identifikasi kesesuaian objek lingkungan dengan KD.

\section{2) Pelaksanaan}

a. Lingkungan dalam pagar sekolah

Guru dalam pembelajaran mata pelajaran IPS di SDN Tasikmadu 02 Palang Tuban dalam mengajar menggunakan sumber belajar yang ada di dalam sekolah. Terutama sumber belajar yang ada di dalam sekolah itu seperti LKS, buku paket, buku perpustakaan dan juga Al Qur"an.

Penjelasan tersebut juga sesuai menurut Abdul Majid dalam bukunya "Perencanaan Pembelajaran". Beliau menyebutkan bahwa sumber belajar adalah segala tempat atau lingkungan sekitar, benda dan orang yang mengandung informasi dapat digunakan sebagai wahana bagi peserta didik untuk melakukan proses perubahan tingkah laku. Sumber belajar diterapkan sebagai informasi yang disajikan dan disimpan dalam berbagai bentuk media, yang dapat membantu siswa dalam belajar sebagai perwujudan dari kurikulum. Sumber belajar yang ada di lingkungan sekolah yang dapat dimanfaatkan 
untuk proses pembelajaran seperti guru, tema sekelas, laboratorium, perpustakaan, buku pelajaran, kamus dan lain-lain. ${ }^{13}$

Hal tersebut juga didukung oleh Syaifurahman dan Tri Ujati dalam bukunya "Manajemen dalam Pembelajaran", beliau menyebutkan bahwa pada dasarnya sumber belajar dapat diperoleh dari sekitar kita sehingga mudah di jangkau, baik yang berada di dalam lingkungan sekolah maupun di luar lingkungan sekolah. Contoh sumber belajar yaitu guru, orangtua,tanaman, daun-daunan, biji-bijian, zat cair,hewan, kejadian atau peristiwa, barang-barang bekas dan barang buatan prabrik. ${ }^{14}$ Hal tersebut juga didukung oleh E Mulyasa dalam bukunya "Menjadi Guru Profesional", beliau menyebutkan bahwa "sumber belajar yang tersedia di sekolah antara lain adalah perpustakaan, media masa, para ahli bidang studi dan sumber-sumber masyarakat. ${ }^{15}$

Terdapat beberapa bentuk pemanfaatan lingkungan sekolah ruang lingkup dalam pagar sekolah, ada beberapa guru yang tetap mengajar didalam kelas yang memberi tugas berupa pengamatan interaksi antarteman, selain itu bentuk lain adalah mengajak siswa untuk keluar kelas yang memberi tugas membuat lubang biopori disekitar sekolah.

b. Lingkungan diluar pagar sekolah terjangkau saat jam pelajaran

Bentuk pemanfaatan lingkungan sekolah yang terjangkau saat jam pelajaran adalah pengamatan kondisi masyarakat sekitar rumah siswa seperti pengamatan pasar malam, ada juga mencari data jumlah penduduk di rumah siswa.

Guru-guru dalam mengajar selain menggunakan sumber belajar yang ada di dalam sekolah juga menggunakan sumber belajar yang ada diluar sekolah. Yang dari luar sekolah itu seperti mushola dan alam sekitar. Penggunaan sumber belajar secara maksimal dapat meningkatkan kualitas pembelajaran.

Penjelasan tersebut juga sesuai menurut Abdul Majid dalam bukunya "Perencanaan Pembelajaran". Beliau menyebutkan bahwa sumber belajar yang ada di luar sekolah meliputi pasar, museum, sungai, gunung, situs, candi dan peninggalan lainnya serta peristiwa atau kejadian-kejadian lainnya. ${ }^{16}$ Guru-guru dalam proses pembelajaran tematik tidak hanya menggunakan metode ceramah saja dalam pembelajarannya,

\footnotetext{
13 Abdul Majid, Perencanaan Pembelajaran, (Bandung: Remaja Rosdakarya, 2012), hal. 170

${ }^{14}$ Syaifurahman dan Tri UJiati, Manajemen Dalam Pembelajaran, (Jakarta: Indeks, 2013), hal.131

${ }_{15}$ Mulyasa, Menjadi Guru Profesional...,, hal. 179.

${ }^{16}$ Majid, Perencanaan Pembelajaran, ...hal. 170
} 
melainkan juga menggunakan beberapa metode pembelajaran yang digabungkan dengan penggunaan sumber belajar. Jadi guru juga mengajak siswa untuk terlibat langsung dalam pembelajaran. Hal ini bertujuan agar siswa dapat memahami materi dan membuat pembelajaran lebih menarik dan menyenangkan. Sehingga siswa tidak cepat bosan ketika menerima pelajaran, yang selanjutnya akan membantu siswa dalam mencapai tujuan pelajaran.

Hal tersebut sesuai dengan pendapat Slameto dalam bukunya "Belajar dan FaktorFaktor yang mempengaruhinya" bahwa metode mengajar adalah cara yang harus dilalui didalam mengajar. Metode mengajae dapat mempengaruhi belajar siswa. Metode mengajar guru yang kurang baik akan mempengaruhi belajar siswa yang tidak baik pula. Agar siswa dapat belajar dengan baik, maka metode mengajar harus diusahakan yang tepat, efisien dan efektif mungkin. Selain itu juga harus ada relasi antara guru dan siswa dalam pembelajaran. Relasi guru dengan siswa baik, membuat siswa akan menyukai gurunya, juga akan menyukai mata pelajaran yang diberikannya sehingga siswa berusaha mempelajari sebaik-baiknya. Guru yang kurang berinteraksi dengan siswa dengan baik menyebabkan proses belajar-mengajar itu kurang lancar. ${ }^{17}$

Dalam pembelajaran IPS lebih menekankan pada praktik secara langsung oleh siswanya untuk mengembangkan potensinya sedangkan gurunya sebagai fasilitator. Guru tidak hanya menerangkan materi yang ada di dalam LKS tetapi juga memanfaatkan sumber belajar yang ada di sekitar lingkungan sekolah. Siswa diajak langsung untuk menemukan dan mencari sendiri tentang materi yang ajarkan baik di dalam maupun di luar kelas.

Hal tersebut sesuai dengan pendapat Rusman dalam bukunya "Pembelajaran Tematik Terpadu Teori, Praktik dan Penilaian" bahwa pembelajaran tematik memiliki karakteristik yaitu berpusat pada siswa (student centered), hal ini sesuai dengan pendekatan belajar modern yang lebih banyak menempatkan siswa sebagai subjek belajar sedangkan guru lebih banyak berperan sebagai fasilitator yaitu memberikan kemudahan-kemudahan kepada siswa untuk melakukan aktivitas belajar. Pembelajaran tematik bersifat luwes/fleksibel di mana guru dapat mengaitkan dan memadukan bahan

\footnotetext{
${ }^{17}$ Slameto, Belajar dan Faktor-Faktor yang Mempengaruhinya..., hal. 70
} 
ajar dari berbagai muatan mata pelajaran, bahkan mengaitkannya dengan kehidupan siswa dan keadaan lingkungan di mana sekolah dan siswa berada. ${ }^{18}$

Dalam pelaksanaan pemanfaatan lingkungan sekolah sebagai sumber belajar siswa pada mata pelajaran tematik, proses pembelajaran di SDN Tasikmadu 02 Palang Tuban menjadi lebih menarik, menyenangkan, lebih terarah dan optimal. Siswa menjadi lebih mandiri, mendapat bnayak pengalaman dan dapat dengan mudah memahami materi pembelajaran secara mendalam. Hal ini sesuai dengan pendapat Rusman dalam bukunya "Pembelajaran Tematik Terpadu, Teori, Praktik dan Penilaian" bahwa Pembelajaran tematik memiliki tujuan sebagai berikut: ${ }^{19}$

a. Mudah memusatkan perhatian pada satu tema atau topik tertentu

b. Mempelajari pengetahuan dan mengembangkan berbagai kompetensi muatan mata pelajaran dalam tema yang sama

c. Memiliki pemahaman terhadap materi pelajaran lebih mendalam dan berkesan

d. Mengembangkan kompetensi berbahasa lebih baik dengan mengaitkan berbagai muatan matta pelajaran lain dengan pengalaman pribadi peserta didik

e. Lebih semangat dan bergairah belajar karena mereka dapat berkomunikasi dalam situasi nyata, seperti bercerita, bertanya, menulis sekaligus mempelajari pelajaran yang lain

f. Lebih merasakan manfaat dan makna belajar karena materi yang disajikan dalam konteks tema/subtema yang jelas

g. Guru dapat menghemat waktu, karena muatan mata pelajaran yang disajikan secara terpadu dapat dipersiapkan sekaligus dan diberikan dalam 2 atau 3 pertemuan bahkan lebih atau pengayaan

h. Budi pekerti dan moral peserta didik dapat ditumbuhkembangkan dengan mengangkat sejumlah nilai budi pekerti sesuai dengan situasi dan kondisi.

Setelah menghubungkan temuan data dari lapangan dengan teori peneliti menemukan bahwa dalam guru di SDN Tasikmadu 02 Palang Tuban menggunakan berbagai macam sumber belajar dalam proses pembelajaran IPS. Dalam memanfaatkan sumber belajar yang ada di lingkungan sekolah dalam meningkatkan hasil belajar siswa, guru dapat

\footnotetext{
${ }^{18}$ Rusman, Pembelajaran Tematik Terpadu Teori, Praktik dan Penilaian (Jakarta: Raja Grafindo Persada, 2015), hal.146-147.

${ }^{19} 3$ Ibid, hal 145-146.
} 
membuat media dan sumber belajar yang menarik agar siswa tertarik dalam mengikuti proses pembelajaran. Seperti siswa diajak untuk belajar di luar kelas, dengan memanfaatkan sumber belajar yang ada di luar kelas seperti taman sekolah dan halaman sekolah. Siswa dapat merasakan suasana belajar yang berbeda, serta dapat mengamati objek secara langsung yang akan menambah pemahaman siswa. Penggunaaan sumber belajar yang bervariasi dalam pembelajaran IPS mendapat respon baik dari siswa, dengan menggunakan sumber belajar yang bervariasi, siswa dapat termotivasi untuk belajar dan dapat mencapai tujuan pembelajaran.

c. Lingkungan di luar pagar sekolah tidak terjangkau saat jam pelajaran

Berdasarkan pendapat guru terkait pemanfaatan lingkungan sekolah sebagai sumber belajar IPS semua sekolah pernah mengajak siswanya untuk belajar di luar sekolah seperti mengajak siswanya ke Malang yang merupakan salah satu program sekolah.

\section{3) Evaluasi}

Hasil dari dokumentasi dan wawancara guru pada tahap terakhir yaitu evaluasi atau tindak lanjut dari pelaksanaan pembelajaran IPS di sekolah, sebagian besar guru memberikan tugas berupa pengamatan di lingkungan sekitar siswa maupun di sekitar sekolah. Untuk hasil belajar siswa, semua siswa telah melampaui KKM yang telah ditentukan oleh guru.Sehingga, pembelajaran yang sudah direncankanan dan dilaksanakan oleh guru telah mampu mencapai tujuan pembelajaran. Bentuk dari tugas ada beberapa macam yakni ada pembuatan video, laporan, makalah, ada juga berupa simulasi langsung.

\section{Kendala-kendala Guru dalam Pemanfaatan Lingkungan Sekolah Sebagai Sumber Belajar SDN Tasikmadu 02 Palang Tuban}

Kendala-kendala yang dihadapi guru ketika memanfaatkan lingkungan sekolah sebagai sumber belajar IPS menemui beberapa kesulitan, seperti kemampuan guru dalam merencanakan pembelajaran, kendala terhadap waktu, sarana dan prasarana yang kurang mendukung, dan antusias siswa terhadap pembelajaran IPS dengan memanfaatkan lingkungan sekolah sebagai sumber belajar IPS. 


\section{Kesimpulan}

Sesuai dengan tujuan pembelajaran IPS yang bertujuan mendorong siswa berpikir kritis, sehingga bidang studi IPS bukanlah bidang studi yang mudah dalam penyampainya, namun sebagian orang beranggapan bahwa IPS cukup disampaikan dengan cara menghafal atau mengingat saja. Pendapat tersebut tentunya akan menjadikan IPS sebagai mata pelajaran yang banyak tidak diminati siswa. Sumber Daya Manusia (SDM) guru pengampu bidang studi IPS seringkali tidak sesuai dengan bidang studinya.

Kualitas Sumber Daya Manusia (SDM) guru yang tidak kompeten berakibat pada penggunaan metode yang juga monoton, banyak guru bidang studi IPS belum menggunakan metode yang inovatif dan bervariasi. Demikian pula dalam penggunakan sumber belajar dan media belajar, biasanya dalam menyampaikan materi pembelajaran guru hanya berpegang pada buku pegangan dan LKS. Lingkungan sekitar baik lingkungan geogrfis, lingkungan ekonomi, lingkungan sosial dan lingkungan budaya belum dimanfaatkan sebagai sumber belajar dan media belajar secara maksimal, padahal keberadaannya sangat dekat dengan siswa.

Apabila potensi-potensi tersebut dimanfaatkan dalam pembelajaran IPS, maka akan memudahkan siswa untuk menemukan dan memahami permasalahanpermasalahan yang ada dilingkungannya dan mampu mendorong anak untuk menemukan solusi keluarnya. Kondisi ini disebabkan selain karena guru kurang dapat menangkap potensi lingkungan sekitar untuk dimanfaatkan sebagai sumber belajar, juga disebabkan karena guru kurang kreatif dalam memilih metode pembelajaran.

\section{Daftar Referensi}

Danusaputro, Munadjat. 1980. Hukum Lingkungan Buku I: Umum, Binacipta, Bandung, 1980, hal. 46

Majid, Abdul. 2012. Perencanaan Pembelajaran. Bandung: Remaja Rosdakarya.

Nursid Sumaatmaja, 1998. Manusia Dalam Konteks Sosial Budaya Dan Lingkungan Hidup. Bandung: Alfabeta.

Rusman, 2013. Model-model Pembelajaran. Jakarta: PT Raja Grafindo Persada.

Rusman. 2015. Pembelajaran Tematik Terpadu Teori, Praktik dan Penilaian. Jakarta: Raja Grafindo Persada.

Sanjaya, Wina. 2008. Perencanaan dan Desain Sistem Pembelajaran. Jakarta: Kencana

Sapriya, 2011. Pengajaran IPS, Konsep dan Pengajaran. Bandung : Remaja Rosda Karya.

Somantri. 2011. M.Numan, Menggagas Pembaharuan Pendidikan IPS. Bandung: Remaja Rosdakarya Offset

Sudjana, Nana. 1989. Dasar-dasar Proses Belajar Mengaja. Bandung: Sinar Baru. 
Sugiyono. 2005. Metode Penelitian Kuantitatif, Kualitatif dan R\&D. Bandung: Alfabeta. Trianto, 2011. Model Pembelajaran Terpadu. Jakarta: Bumi Aksara.

Wahab, Abdul Azis, 2007. Metode dan Model-Model Mengajar Ilmu Pengetahuan Sosial (IPS). Bandung : Alfabeta. 